\title{
Kewirausahaan Ayam Bakar MANTUL (Mantap Betul)
}

\author{
Nirwanto Palangi, Nata Mandala
}

\section{BAB I}

\section{PENDAHULUAN}

Pada masa kini, perkembangan-perkembangan yang terjadi di dunia usaha sangat terlihat, di mana banyak usahawan-usahawan baru yang banyak bermunculan dengan inovasiinovasi baru yang berhasil dicipakan. Secara khusus usahawan-usahawan yang bergelut pada usaha bidang kuliner, di mana begitu banyak timbul ide-ide yang dimunculkan oleh para usahawan untuk membuat jenis-jenis makanan yang menarik dan laku dalam penjualannya.

Contoh yang dapat dilihat yaitu di kalangan para mahasiswa, artis dan masyarakat pada umumnya, yaitu banyak membuat jenis usaha makanan, minuman yang bervariasi dan sangat menarik. Khusus pada jenis usaha kuliner ini, sangat terlihat perkembangannya pada masa kini, hanya perlu melihat di internet, tentang produk makanan yang diciptakan yang begitu menarik dan bervariasi, juga memiliki nama produk yang unik, bahkan nama dari produk tersebut menjadi banyak diketahui oleh banyak konsumen, oleh karena keunikan dan kualitas produk tersebut. Sebagai contoh: dari kalangan artis yang membuka usaha, yaitu Ruben Onsu, yang membuat suatu produk makanan, yang dinamakan Ayam Geprek, dan usaha ini cukup terkenal dikalangan masyarakat sekitarnya. Keunikan dan kualitas dari produk inilah yang mebuat ayam geprek ini terkenal. Tentunya pada usaha kuliner, begitu banyak orang-orang yang telah mengusahakan pada bidang ini, dan juga begitu banyak jenis kuliner yang telah dibuat, dengan keunikan dan kualitasnya masing-masing. Di mana-mana pasti ada penjual kuliner.

Melihat dari perkembangan pada usaha kuliner, membuat penulis tertarik untuk mencoba menggeluti usaha pada bidang ini. Pemikiran dasar mengapa penulis ingin memulai usaha, yaitu dengan melihat realita kebutuhan semua orang, di mana setiap hari semua orang mencari makanan, oleh karena itu merupakan kebutuhan yang harus dipenuhi dan semua orang pada masa kini diberikan begitu banyak tawaran kuliner yang beraneka ragam. Oleh karena itu, penulis berkeinginan untuk menggeluti usaha pada bidang kuliner. Adapun jenis kuliner yang ingin dibuat yaitu "Ayam Bakar" yaitu suatu jenis kuliner yang biasa dinikmati dikalangan masyarakat. Namun ide dari kuliner ini tentunya memiliki suatu keunikan yang ingin ditawarkan oleh penulis kepada konsumen, yang membedakan kuliner ayam bakar ini berbeda dari ayam bakar pada umumnya. Ide tentang ayam bakar yang akan dibuat adalah ayam bakar utuh, yaitu porsi satu badan ayam utuh yang dibakar dan ayam bakar ini merupakan porsi besar, yang dapat dinikmati oleh beberapa orang, dan cocok untuk paket keluarga. 
Mengenai sumber bahan utama (ayam) untuk usaha ini, penulis akan bekerja sama dengan pihak peternak ayam terdekat, yang memungkinkan kemudahan bagi penulis untuk menjalankan usaha, dan bahan lainnya (bumbu) penulis juga akan bekerja sama dengan pihak penjual bumbu terdekat. Untuk bahan-bahan pembuatan ayam bakar ini sangat terjangkau, dan inilah yang menjadi salah satu kekuatan dalam rencana usaha ini. Dan hal lain yang menjadi peluang bagi penulis untuk membuka usaha ini yaitu, keunikan porsi ayam bakar yang akan dibuat, yaitu ayam bakar paket keluarga (satu ayam utuh), penulis melihat sangat jarang yang menjual ayam bakar dengan paket besar, pada umumnya ayam bakar yang dijual adalah ayam bakar dengan porsi kecil. Dari hal ini, penulis merasa bahwa ini merupakan peluang untuk membuka usaha ini.

\section{BAB II \\ Lokasi Penjualan}

Lokasi di mana penulis akan membuka usaha, yaitu di daerah perkotaan tempat penulis tinggal, tepatnya di tengah kota Makassar. Tempat di mana penulis akan membuka usaha merupakan tempat yang cukup strategis, oleh karena tempat atau lokasi penjualan berada di tengah keramaian kota, dan lokasi penulis pun sangat mendukung bagi kemudahan akan kebutuhan-kebutuhan yang diperlukan bagi berjalannya usaha ini seperti, tempat penjual ayam dan pasar tempat membeli bumbu dekat dengan lokasi usaha, sehingga sangat memudahkan bagi kelancaran menjalankan usaha. Tempat penjualan ayam merupakan tempat di mana ayam diternakan, sehingga penulis dapat menjalin kerja sama dengan peternak ayam. Dan hal lainnya, yaitu seperti alat transportasi, penulis menggunakan alat tarnsportasi sendiri (motor).

Dengan lokasi usaha yang cukup baik untuk membuka usaha, yaitu di tengah keramaian kota, maka hal tersebut sangat memberi jaminan untuk perkembangan bagi usaha ini. Karena keramaian masyarakat juga menentukan tingkat penjualan, di mana terdapat keramaian, di sana ada peluang besar terhadap tingkat penjualan, dan sukses atau tidaknya sebuah usaha tentunya tidak hanya ditentukan oleh faktor keramaian tersebut dan pemilihan tempat yang strategis, melainkan ada beberapa faktor lain yang juga membuat suksesnya suatu usaha, seperti keunikan produk, kualitas dari produk tersebut. 


\section{BAB III}

\section{Metode}

Beberapa referensi yang digunakan adalah: proposal kegiatan kreativitas ${ }^{1}$ sebagai contoh proposal. Untuk kajian yang lain untuk mendeskripsikan tulisan proposal ini menggunakan pendekatan kualitatif deskripsi ${ }^{2}$, dan pembuatan laporan atau makalah diberikan contoh karya ilmiah Kewirausahaan Nameko (Nasi merah kotak-kotak). ${ }^{3}$ Topik yang diangkat dalam kewirausahaan ini adalah berbahan ayam yang dibakar dengan sebutan ayam bakar MANTUL (Mantap Betul).

\section{Metode Pelaksanaan \\ Cara Pembuatan}

Cara pembuatan ayam bakar mantul ini sesungguhnya tidak terlalu jauh berbeda dari pembuatan ayam bakar pada umumnya, mungkin hanya ada beberapa perbedaan dari cara pembuatan ayam bakar ini. Adapun cara pembuatan ayam bakar ini, sebagai berikut:

Pertama:

Sediakan ayam satu ekor utuh yang sudah dibersihkan, kemudian rendam ayam dengan air jeruk nipis. Guna mengurangi bau amis pada daging ayam. Jangka waktu untuk merendam ayam dengan air jeruk yaitu sekitar 15 menit.

Kedua:

Rebus ayam yang sudah direndam, sampai setengah matang yaitu guna membuat tekstur daging ayam lebih halus dan empuk.

Ketiga:

Setelah ayam direbus setengah matang, dinginkan ayam sejenak untuk kemudian dapat dioleskan dengan bumbu.

Keempat:

Siapkan bumbu yang akan dioleskan pada ayam. Bumbu yang dipersiapkan yaitu: bawang putih dan bawang merah halus, serai halus (yang sudah diblender), merica bubuk dan campurkan dengan minyak goreng dan sedikit kecap manis. Dan bumbu inilah yang akan dioleskan pada ayam ketika dibakar.

Kelima:

\footnotetext{
1 Jonathan Matheus et al., "Proposal Kegiatan Kreativitas Handmade BOLU (Boneka Lucu)," 2019, https://osf.io/nwdap/.

${ }^{2}$ Hengki Wijaya and Helaluddin Helaluddin, Analisis Data Kualitatif Sebuah Tinjauan Teori \& Praktik (Makassar: Sekolah Tinggi Theologia Jaffray Makassar, 2019).

${ }^{3}$ Hengki Wijaya and Tuflikha P. Putri, "KEWIRAUSAHAAN NAMEKO (NASI MERAH KOTAKKOTAK) DALAM MENGGIATKAN PANGAN LOKAL YANG SEHAT" (Prosiding Seminar Nasional Pangan, Teknologi, dan Entrepreneurship, Makassar, Indonesia: Universitas Fajar Makassar, 2019), https://osf.io/vzd48.
} 
Mempersiapkan tempat pemanggang (arang yang dipakai untuk membakar dan tempat pemanggang) dan alat-alat seperti sendok penjepit dan kipas.

Keenam:

Setelah ayam telah dioleskan dengan bumbu, ayam siap di panggang (ayam terus dioles dengan bumbu selama proses pemanggangan, hal ini dilakukan untuk membuat ayam yang dipanggang teresapi dengan bumbu dan tidak kering.

Ketujuh:

Selama menunggu ayam dibakar atau dipanggang, maka siapkanlah bumbu utama untuk disalutkan pada ayam yang sudah matang. Bumbu ini merupakan bumbu utama untuk menciptakan cita rasa khas pada ayam bakar ini. Yaitu bumbu sambel asem pedas. Adapun bahan-bahan yang diperlukan untuk membuat bumbu ini yaitu : bawang merah/putih, serai, merica, lombok dan kunyit (yang sudah diblender)dicampurkan, setelah itu tumis sampai mengeluarkan bau wangi bumbu dan campurkan saus tiram serta saus tomat. Setelah bumbu disiapkan, ayam siap dilumuri dengan bumbu tersebut, yaitu bumbu sambel asem pedas dan inilah yang akan menjadi cita rasa ayam bakar tersebut.

\section{Pengemasan}

Setelah ayam telah matang, maka ayam siap dikemas yaitu dengan kemasan mika plastik. Dalam kemasan juga dihiaskan dengan beberapa tambahan pelengkap, seperti potongan tomat, timun, daun kemangi serta daun kol. sebagai dasar untuk kemasan, harus meletakkan kertas minyak agar membuat tampilan kemasan lebih baik.

\section{Memasarkan}

Cara pemasaran, yaitu dengan menjual di tempat, dengan membuat warung tempat di mana ayam bakar dijual, dan cara lain yaitu dengan simtem online, yaitu dengan adanya Grabfood, sangat mempermudah untuk pemasaran dan cara lainnya yaitu dengan menerima pesan antar.

\section{BAB IV \\ Anggaran dana}

Dengan memperhatikan proses pengelolahan ayam bakar mantul, maka dana awal di dapat dari yuran anggota kelompok yang beranggotakan empat orang Rp. 100.000,00/orang Jadi modal ayam bakar mantul Rp.400.000,00.

Biya untuk perlengkapan:

$>$ Membeli ayam 7 ekor. Harga ayam satu ekor Rp. 35.000,00 x 7 ekor $=$ Rp.245.000,00

$>$ Membeli Bawang merah 2 ons Rp.5.000,00

$>$ Bawang putih 3 siung Rp.5.000,00

$>$ Membeli bawang bombai $1 \mathrm{~kg} \mathrm{Rp} .25 .000,00$

$>$ Membeli jeruk 6 biji Rp.3000,00

$>$ Membeli saus Lombok 2 botol yang sedang Rp.24.000,00

$>$ Membeli serai Rp.2.000,00

$>$ Membeli jahe 2 siung Rp. 3.000,00

$>$ Membeli arang 2 kantong plastik sedang Rp.20.000,00

$>$ Membeli caberawit 2 on Rp.5.000,00

$>$ Membeli cabe merah Rp.2.000,00

$>$ Membeli mika 7 bua Rp 20.000,00

$>$ Membeli Kecap satu botol kecil Rp.5.000,00

$>$ Membeli minyak goreng $1 \mathrm{~kg} \mathrm{Rp.14.000,00}$ 
Membeli Tomat 2 on Rp.7.000,00

$>$ Lain-lain Rp.10.000,00

Total keseluruhan dana: Rp.395.000,00.

Jadwal kegiatan:

Kegiatan ini akan dilaksanakan pada hari sabtu tanggal 10 Agustus 2019.

\begin{tabular}{|l|c|c|}
\hline No & Jenis pengeluaran & biaya \\
\hline 1 & Perlengkapan yang diperlukan & Rp. 25.000 \\
\hline 2 & Bahan habis pakai & Rp. 355.000 \\
\hline 3 & Perjalanan & Rp. 10.000 \\
\hline 4 & Lain-lain & Rp. 30.000 \\
\hline 5 & Total & Rp. 420.000 \\
\hline
\end{tabular}

\section{Daftar Pustaka}

Matheus, Jonathan, Hengki Wijaya, Grace Irene Kalamu, and Josevina Maria Penfani. "Proposal Kegiatan Kreativitas Handmade BOLU (Boneka Lucu)," 2019. https://osf.io/nwdap/.

Wijaya, Hengki, and Helaluddin Helaluddin. Analisis Data Kualitatif Sebuah Tinjauan Teori \& Praktik. Makassar: Sekolah Tinggi Theologia Jaffray Makassar, 2019.

Wijaya, Hengki, and Tuflikha P. Putri. "KEWIRAUSAHAAN NAMEKO (NASI MERAH KOTAK-KOTAK) DALAM MENGGIATKAN PANGAN LOKAL YANG SEHAT." Makassar, Indonesia: Universitas Fajar Makassar, 2019. https://osf.io/vzd48. 